\title{
EMPLOYABILITY AND HIGHER EDUCATION: THE CASE STUDY OF ESTM MASTER'S DEGREE
}

\author{
A. Viana, S. Pais, A. Sousa, M. Schön \\ Polytechnic of Leiria, School of Tourism and Maritime Technology, CiTUR (PORTUGAL)
}

Citation

Viana, A., Pais, S., Sousa, A., Schön, M. (2019), Employability and Higher Education: The Case Study of ESTM Masters' Degree". In EDULEARN19 Proceedings, pages: 399-407. (ISBN: 978-84-09-120314. ISSN: 2340-1117). Conference name: 11th annual International Conference on Education and New Learning Technologies. Conference held in Palma de Mallorca, Spain, 1st-3rd of July, 2019. DOI:10.21125/edulearn.2019.0139

\begin{abstract}
The labor market in this globalized world, based on new technologies, is constantly changing. In an increasingly demanding and dynamic world of human resources competences, young people have to focus on their training in order to enter in the labor market better prepared and thus contribute to the success of the entity that receives them and for their own professional and personal fulfillment. The choice of their academic journey is crucial to ensure the achievement of these competences and make that decision is not easy, with a system of higher education such as the Portuguese, where there are so many graduation courses and two systems of teaching, University and Polytechnic. In fact, with the changes introduced in higher education by the so-called Bologna Process, most undergraduate's courses saw the number of years reduced from five to three years, while others opted for integrated master's degrees. In the case of the School of Tourism and Maritime Technology, the option was to offer three-year degree courses and two-year master's degrees. This study intends to understand where are the students who have bet on their training at the master's level and finish their master's degree at the School of Tourism and Maritime Technology (ESTM) of the Polytechnic of Leiria, if they are working in the area and if the employers recognize these qualifications.
\end{abstract}

\section{Keywords: Higher Education, Master's degree, Employability, Human Resources}

\section{INTRODUCTION}

Over the last few years the competitiveness has been increasing at all levels in society, the world economy is becoming increasingly dominated by services and knowledge, and in education market is the same [1].

Services have been the fastest growing international trade sector in recent decades, and education is part of this sector [2]. The integration and globalization of international markets have contributed to increasing the competitive pressure among competitors in the international economy, with repercussions on education systems in different countries [3].

The growing number of Higher Education Institutions (HEls), both national and international, compete with each other in a fierce way for the recruitment of new students, and therefore candidates for Higher Education have become more critical and analytical in their decision-making to choose an institution to study ([4], [5], [6]).

In this context, HEls should be guided by the experiences and good practices already adopted by industrial and service companies, which have tried to respond to the clients demands in terms of the services perceived quality. However, this concept has been subject to great attention in the business community due to its practical implications for customer satisfaction [7].

International tourism, another of the service sectors, has also been rapidly evolving since the end of the 1970s [8]. This high level of growth of the tourism and hotel industry across the world presents many career opportunities and allows academics and tourism professionals to create different paths to the career of current and potential employees in the area. [9]. 
Amoah e Baum [10] ensure that tourism is a labor-intensive industry that depends heavily on the availability of well-qualified professionals for their survival and to being able to provide, operate and manage the tourism product, since the interaction between tourist and personal of tourist companies represents an integral point of the total tourist experience.

Despite this need for well-qualified professionals, tourism, and especially hotel industry have often struggled with negative perceptions about practices and employment conditions and this perception has often been confirmed with reality [11].

In this sense, it is important to understand the link between higher education and the labor market, to know if current higher education institutions are responding to these challenges and to be able to train the appropriate professionals to provide a quality service that meets the requirements of current customers. A good professional need skills and need training to be able to provide good service in the companies where they will work.

Eurico et al. [12] point out that HEls face additional challenges that are often measured by students' level of satisfaction with image, expectations, value, and loyalty. In the opinion of Finch et al [13] some of them strive to promote in tourism students the love of lifelong learning and community involvement.

Thus, one of the objectives of this study is also to understand if the newly graduates see their investment in higher education as an added value for entry into the labor market and if companies also recognize and value this training, more concretely at the masters level degree.

To this end, we will studying the case of the Master in Hotel Management of the School of Tourism and Maritime Technology, of the Polytechnic of Leiria, and try to understand if the expectations of the students regarding to this higher education were translated into practice by a career opportunity and a better performance than a bachelor's degree.

\section{LITERATURE REVIEW}

\subsection{Higher Education in Portugal}

In general, Higher Education is characterized by two subsystems: the university and the polytechnic. This division is currently the reality in Portugal, assumed in the national legislation (Law no. 62/2007, in its article 3, of September 10 - Legal Regime of Institutions of Higher Education). In other European countries this situation is similar, since in some cases the polytechnics have been transferred to the university universe, with more or less change of designation and / or mission and in other cases, with a clear separation.

In Portugal, there are 39 public HEls, both in university and polytechnic subsystem, and there are 81 private HEls, both in university and in polytechnic subsystem.

According to Alves and Raposo [14], there has been a radical change in higher education in the last two decades in Portugal, as has happened in other European countries and in the USA, with HEls facing increasing competition, competing for different financial resources, which are increasingly scarce, in order to meet the growing demand of new students who are applying to HEls at international level.

Phenomena such as globalization and the Bologna Convention have made tourism education gain more interest since the last quarter of the 20th century [15]. Although some of the courses in Tourism may have been created in the 1930s [16] and 1940s [17], such movement began to take shape more concretely in the 1960s and 1970s in some pioneering universities [18]. For Jenkins [18], education in tourism was a product of English universities and, more recently, by the education systems in the rest of Europe. The great boom in tourism education came after the emergence of post-World War II mass tourism, also known as "Fordian Tourism", which sparked a massive demand for workers in the postwar tourism industry [19]. Another vital factor for the growing importance of tourism education was the increase of international recognition for the value of tourism activities [15]. In Jenkins view [18], it is clear that tourism education originated in Europe and then spread to the USA, Canada, Australia and New Zealand. This development is also related to the globalization which increased the competition to attract domestic and foreign students. This has led the Higher Education Institutions (IES) to recognize the need to promote and commercialize their services to face the increasing competitiveness between them [20]. 
It was in Switzerland that in 1893 the first School of Tourism in Europe was launched, the École de Hôtelière de Lausanne [21], founded by the local Hotel Association, which represented a kind of milestone in the creation of a solid base of teaching and research in tourism worldwide.

On the other hand, the first Hotel Management course, launched in the USA, was at the Cornell School of Hotel Administration at Cornell University in 1922 ([21], [22]) on the initiative of some hotel business magnate and the American Hotel Association AHA.

In Portugal, according to Brito [23], until the 1950s, there are many proposals on the need to value human resources. Until, on February 17, 1954, there is a proposal of a law of the Government, which in its article 17 says: "it is incumbent upon the Tourism services to promote the creation of hotel schools for the professional training of hotel industry personnel and the like and to decide on the program of the courses "[23]. The proposal is approved by the Legislative Commission of the Assembly of the Republic and becomes article18 of Law 2073. In 1955, Jorge Felner da Costa criticizes the fact that it does not attend to the training of personnel for the tourist area [23]. An Ordinance dated 30/11/1955, published on 03/12/1955, states: "the Government of the Portuguese Republic is instructed by the Presidency of the Council to set up a Commission to study the creation of hotel schools" [23]. They meet for the first time on 1/4/1956 and then pay a visit to Lausanne, Geneva, Paris, Brussels, Madrid and Thonon les Bains [23]. In 1957 (Diário do Governo II Série de 16 de Outubro) the Statutes of the Professional Schools of the Hotel Industry are published [23].

According to Brito [23], the Professional School of the Hotel Industry of Lisbon was inaugurated in December 1958. In 1967, it began in Funchal. Decree-Law 46354 of 5/5/65 creates the National Center for Hotel and Tourism Industry Training [23]. Also, according to Brito [23], in 1963 there was a Congress of Tourist Studies, where ISLA (Higher Institute of Languages and Administration) explains the reasons for its foundation. Decree-Law 333/79 of 24 August creates the National Tourist Training Institute-INFT (later named INFTUR - beginning of the 2000s) now absorbed by Turismo de Portugal, which manages the network of Professional Schools, at the moment in phase of restructuring. In February 1964 the Institute of New Professions (a private institution) began its activity with post-secondary courses [23].

Tourism courses in Portugal started in the 80's, at the level of Higher Education, but only from the 90's onwards they became generalized, mainly in the scope of polytechnic subsystem [24].

In 1986, the first courses of Tourism were implemented in three private HEls [25], among them the Higher Institute of Languages and Administration - ISLA, the Institute of New Professions of Lisbon and the Superior Institute of Administration and Management of Porto [26]. Only from 1988, the public university system began to integrate this formation in the University of Aveiro ([25], [26]). The Estoril School of Hospitality and Tourism opened the doors to Tourism and Hospitality courses, beginning in 1991, under the umbrella of INFT [26].

According to Schön [27], in the academic year of 2014/15 there were a total of $118 \mathrm{HEls}$ in the Higher Education system in Portugal, of which $41(35 \%)$ had Tourism Licensure Courses, distributed by 24 public HEls and 17 private partnerships. The $41 \mathrm{HEls}$ monitored a total of 73 Courses in the area of Tourism, 51 of which were public and 22 were private.

\subsection{Employability in Hospitality}

For Moreland [28], employability is a set of skills, knowledge, and personal attributes that make individuals more likely to gain employment and to be successful in their chosen occupations, which benefits the workforce, the community and the economy. According to Wang \& Tsai [29], employability can only be improved by absorbing up-to-date professional knowledge, professional development planning and the acquisition of transferable skills in a rapidly growing and changing world economy. As a professional you can achieve your goals of finding a job or starting a business only through strong employability.

According to Wakelin-Theron [30], there is a lack of consensus as to the meaning and measurement of the term of employability. An individual has more freedom today to decide on his career than in the past, where the organizations made this decision for their employees, so there was a change in the responsibility of the decision to choose a career, moving from the company to the individual [31].

But in the hotel sector, employability, despite the growth in the number of hotel establishments in Portugal, is still not very attractive for young people to make a career.

According to Nickson [32] tourism and hospitality often struggle with negative perceptions about employment practices and conditions and this perception has often been confirmed in reality. Keep and 
Mayhew, [33] suggest that this sector has a number of personnel problems, including: generally low wages, unsocial hours and shift patterns that are not family friendly; over-representation of women and ethnic minorities in low-level operational positions; higher status and more skilled jobs filled by men and with better remuneration, pointing to underdeveloped equal opportunities policies in the sector; poor or non-existent career structures and the use of casualized seasonal employment; over reliance on informal methods of recruitment; lack of evidence of good staff management practices / human resources management practices; little or no trade union presence; high levels of labor turnover; difficulties in recruitment and retention of employees.

We present in the tables below the data regarding the number of workers in Hospitality and Restaurant industry as well as the average salaries of the last years.

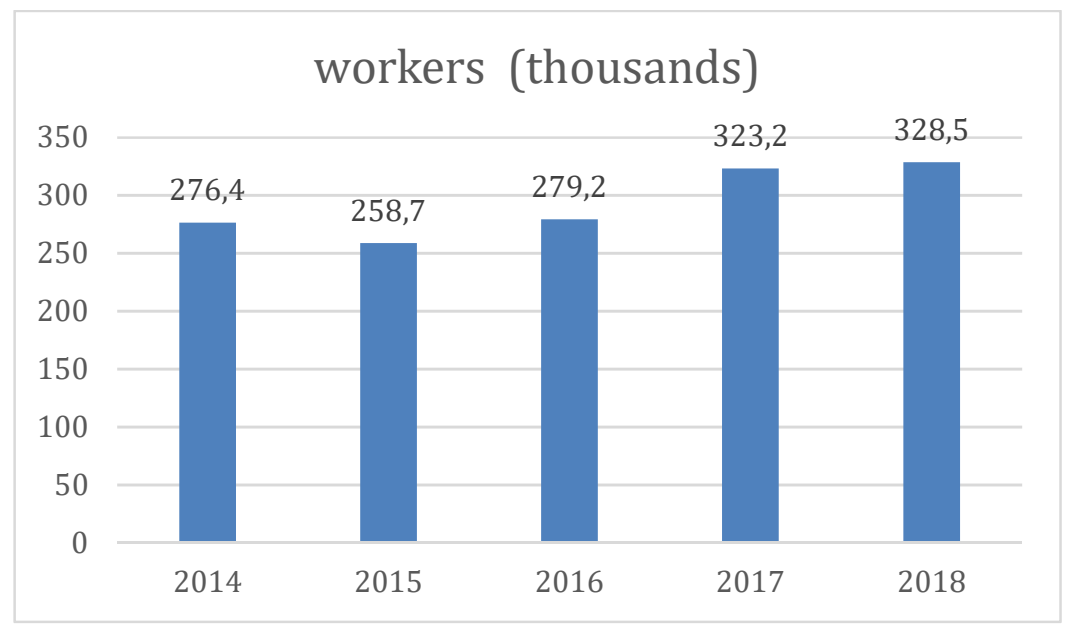

Graphic 1 - Number of workers in Hospitality and Restaurant Industry (Portugal)

Source: INE

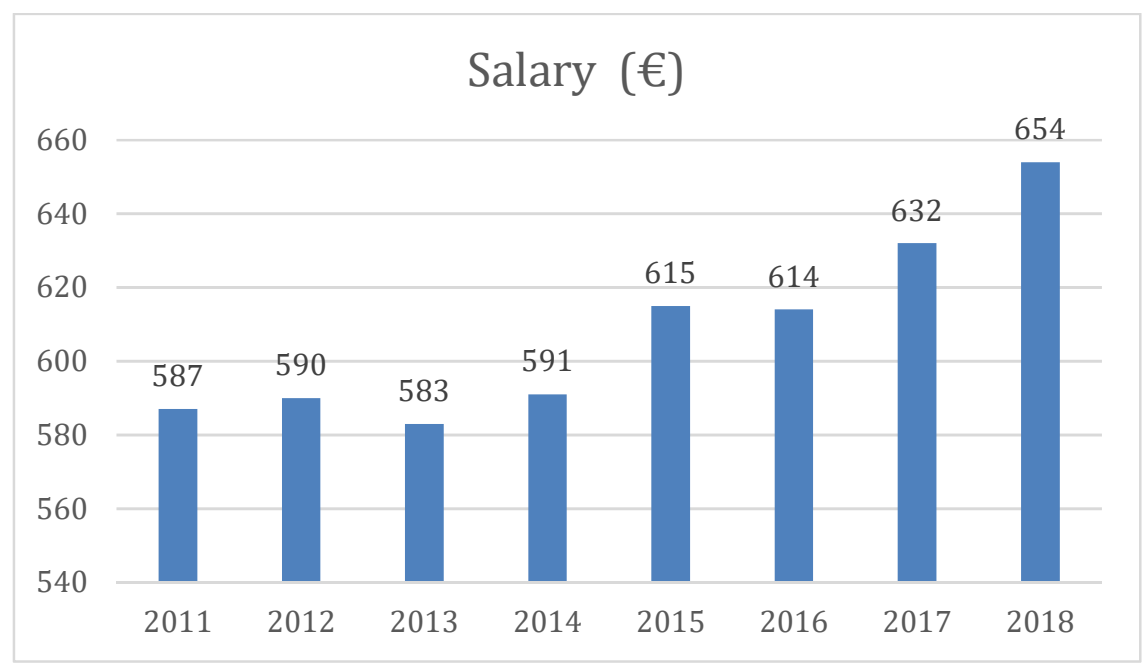

Graphic 2 - Salary in Hospitality and Restaurant Industry (Portugal)

Source: INE 


\subsection{Masters in Hotel Management and Administration}

In Portugal, higher education has been bet on the masters' degree in the area of Hotel Management, counting at least six courses of this type.

Table 1. Masters in Hotel Management and Administration

\begin{tabular}{c|c|c}
\hline \hline Masters & Higher Education Institutions & Local \\
\hline Administration and Hotel Management & $\begin{array}{c}\text { Escola Superior de Gestão, Hotelaria e } \\
\text { Turismo }\end{array}$ & Algarve \\
\hline Administration and Hotel Management & Universidade Lusófona & Porto \\
\hline Hotel Administration & $\begin{array}{c}\text { Escola Superior de Estudos Industriais e de } \\
\text { Gestão }\end{array}$ & Porto \\
\hline Tourism and Hotel Management & Universidade Europeia & Lisboa \\
\hline Hotel Management & Escola Superior de Turismo e Tecnologia do \\
Mar & Peniche \\
\hline Hotel Management & Escola Superior de Hotelaria e Turismo & Estoril \\
\hline \hline
\end{tabular}

Source: Author's Elaboration

For the study of this article we will inquire the students of the Masters in Hotel Management of the School of Tourism and Maritime Technology (ESTM), so it is important to present the course in greater detail in order to perceive its objectives and the skills and training to be acquired by the students and thus, later, understand the results obtained in the study that this article proposes to carry out.

This course has been in the school since the academic year of 2011-2012, in post-work hours, and has as main objectives: to continue the training of the 1st cycle of ESTM courses in the Tourism area; to develop skills to perform the functions of the Hotel Management, through the acquisition of knowledge and tools to assist the management of operational decisions; to increase a professional development for those who aspire to an adequate technical and scientific preparation in the hotel industry; to develop research in the areas of Hotel Management, including the development of dissertations and projects in the Hospitality area; to carry out advanced consultancy studies on complex issues in this area; and develop a connection with the hotel in the region through internships, providing the solution of identified management problems.

The master has a duration of four semesters, the first two of which comprise 12 subject (E-Business, Hotel Operations Management, Financial Management in Hospitality, Relationship Marketing, Research Methodologies, Seminars I and II, Human Resource Management, Project Management, Strategic Management, Promotion of Tourism and Hospitality, Quality and Excellence in Hotel Management and the third and fourth semesters for the development of dissertation, project or internship.

In the following table we present the numbers of students enrolled and graduates of this Master's degree from ESTM.

Table 2. Number of students enrolled and graduates in the Masters of Hotel Management of ESTM

\begin{tabular}{c|c|c|c}
\hline \hline Years & $\begin{array}{c}\text { Enrolled in } \\
\text { the 1st year }\end{array}$ & $\begin{array}{c}\text { Enrolled in the 2nd } \\
\text { year }\end{array}$ & Graduates \\
\hline $2011-2012$ & 31 & 0 & 1 \\
\hline $2012-2013$ & 27 & 21 & 12 \\
\hline \hline
\end{tabular}




\begin{tabular}{c|c|c|c}
\hline \hline $2013-2014$ & 31 & 28 & 9 \\
\hline $2014-2015$ & 20 & 31 & 13 \\
\hline $2015-2016$ & 29 & 25 & 5 \\
\hline $2016-2017$ & 23 & 37 & 7 \\
\hline $2017-2018$ & 12 & 35 & 9 \\
\hline Total & 173 & 177 & 56 \\
\hline \hline
\end{tabular}

Source: Author's Elaboration

We can verify that of the 173 students who enrolled in the Master of Hotel Management during the 7 academic years, since its entry into operation in the academic year 2011-2012 until the academic year 2017-2018, only 56 students completed and have obtained their diploma, which corresponds to $31.6 \%$.

This percentage is quite low compared to the number of students who have completed their first year of study. We can see that in total terms in the second year there are more enrolled students (177 students) than in the total number enrolled in the first year (173 students), which is due to the fact that 4 students entered by equivalence for the second year.

The years with the highest number of graduates, compared to those enrolled in the second year, was the year 2012-2013, with $57.1 \%$ and $2014-2015$, with $41.9 \%$.

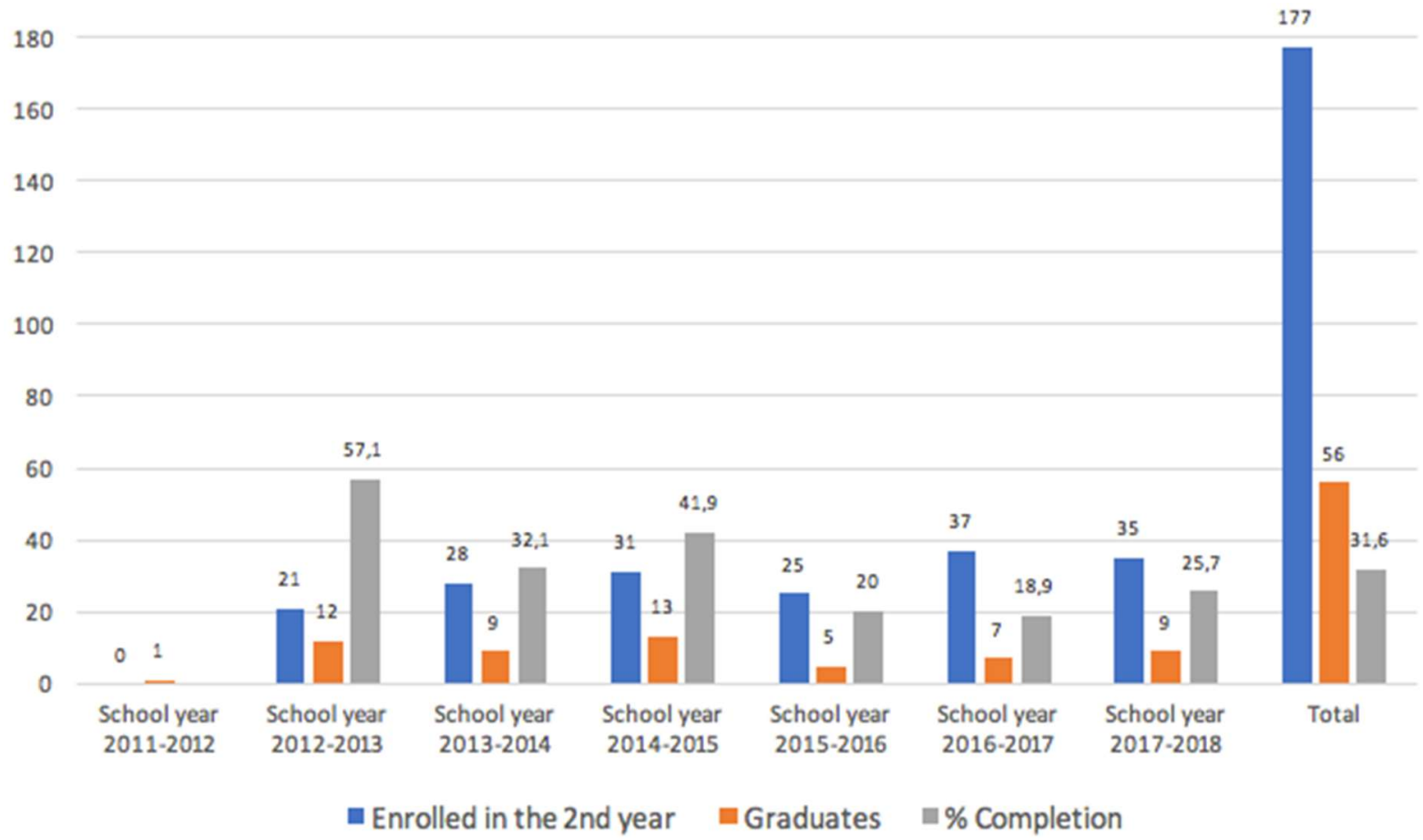

Graphic 3. Percentage of graduate students for years

Source: Author's Elaboration

\section{METHODOLOGY}

For the accomplishment of this study we will apply inquiries, by email, to the total of masters in Hotel Management, through a structured questionnaire. If necessary, interviews will also be held. 
The construction of the questionnaire was based on a review of the literature, as well as the question of research formulated and the identification of the relevant variables. The mixed questionnaire was chosen, which includes open, closed and multiple choice questions.

A first version of this instrument was analyzed by 4 professors of the Higher Education, tested with two elements of the same universe of the respondents and altered in function of the suggestions collected and difficulties detected in their completion.

Once all the questionnaires have been collected, the data will be analyzed and interpreted through the statistical software Statistical Package for Social Science (SPSS) in version 24, which will allow us to organize, present, analyze and interpret the data through statistics descriptive variables, correlation of variables and hypothesis tests.

\section{CONCLUSIONS}

Hotel organizations, as well as other service organizations and companies, are in a quasi-continuous state of change. Some of the changes are gradual, others are more dynamic. These changes result from several factors, both the external environment and the internal environment of the organization [34].

Organizations to be effective need effective managers and collaborators who can respond to these changes and challenges.

The role of higher education institutions is important in preparing the human resources indispensable to enterprises and organizations, because organizations are what their human resources make of them. The importance of people in organizations is immense because it's people who plan, design, implement, sustain and end the life of an organization [35].

It is thus necessary to understand whether higher education institutions are doing their job and preparing the human resources for the organizations and whether organizations recognize and value these formation.

In this sense, we will apply a questionnaire to the graduates of this Master of Hotel Management and draw the proper inferences about their professional situation, their expectations regarding their professional situation in the future, and then we can suggest some strategies to valuing this higher education. As future lines of research, it is our objective to extend the study to other masters of the School of Tourism and Maritime Technology of the Polytechnic of Leiria.

\section{ACKNOWLEDGEMENTS}

This article is financed by national funds through FCT - Fundação para a Ciência e a Tecnologia, I.P., under the project reference number UID/ GES / 04470/2019

\section{REFERENCES}

[1] Altbach, P. G., "Higher education and the WTO: Globalization run amok". International Higher Education, 23 (Spring), 2-4, 2001.

[2] Metcalfe, J. S. \& Potts, J., "Internationalization of services - the evolutinary perspective". Manchester Business School. Working Paper n. 531, 2007. Accessed 19 October, 2018. Retrieved from http://www.mbs.ac.uk/cgi/apps/research/working-papers/view/?wld=138

[3] Ivy, J., "Higher education institution image: a correspondence analysis approach. The International Journal of Educational Management", 15(6), 276-282, 2001.

[4] Binsardi, A. \& Ekwulugo, F., "International marketing of British education: research on the students' perception and the UK market penetration". Marketing Intelligence \& Planning, 21(5), 318-327, 2003.

[5] Maringe, F., "University And Course Choice - Implications for positioning, recruitment and marketing". International Journal of Educational Management, 20(6), 466-479, 2006.

[6] Gallarza, M.G., Fayos, T., Servera, D. \& Arteaga, F. "Análisis e evaluación del servicio de formación universitaria: implicaciones para el marketing estratégico de las universidades". International Congress "Marketing Trends". E.-E.-E. S. o. Management. Venice, 2008. 
[7] Al-Alak, B. A. M., "Measuring and evaluating business students' satisfaction perceptions at public and private universities in Jordan". Asian Journal of Marketing, 3, 33-51, 2009.

[8] Akkemik, K.I., "Assessing the importance of international tourism for the Turkish economy: A social accounting matrix analysis". Tourism Management, 33(4), 790-801, 2012.

[9] Ghuangpeng, S., "Factors Influencing Career Decision-Making: A Comparative Study of Thai and Australian Tourism and Hospitality Students (Doctor of Philosophy)". Victoria University, Melbourne, 2011. Accessed 12 March, 2019. Retrieved from vuir.vu.edu.au/19360/1/Siriwan_Ghuangpeng.pdf

[10] Amoah, V. \& Baum, T., "Tourism education: Policy versus practice". International Journal of Contemporary Hospitality Management, 9(1), 5-12, 1997.

[11] Nickson D., Human Resource Management for the hospitality and tourism industries, ButterworthHeinemann, 2007.

[12] Eurico, S., Oom do Valle, P. Silva, J.A., "Satisfaction in tourism-relation, higher education: the graduates" perspective". International Journal of Academic research. Part B; 5(4), 35-49, 2013

[13] Finch, D., Nadeau, J. \& O'Reilly N., "The future of marketing education: a practitioner's perspective". Journal of Marketing Education, (35)1, 54-67, 2012.

[14] Alves, H. \& Raposo, M., "The influence of university image on student behaviour. International Journal of Educational Management", 24(1), 73-85, 2010.

[15] Munar, A.M., "Is the Bologna process globalizing the tourism education?" Journal of Hospitality, Leisure, Sport and Tourism Education, 6(2), 68-82, 2007.

[16] Jafari, J., "Research and scholarship: the basis of tourism education". Journal of Tourism Studies, 1, 33-41, 1990.

[17] Majó, F.J., "Grado en Turismo. Universitas de Girona", 2004. Accessed 10 November, 2014. Retrieved from http://www.uned.es/espacio-europeo/pdf/Libro-blanco-Turismo.pdf.

[18] Jenkins, C. I., "Tourism educational systems, institutions and curricula: standardization and certification in human capital". In: WTO, The Tourism Industry of the 21st Century, 215-222. Madrid: WTO, 1997.

[19] Fayos-Solá, E., "Educación y formación en la nueva era del Turismo: la visión de la OMT". In: E. Fayos-Solá (ed.) Human Capital in the Tourism Industry of the 21st Century (pp. 59-79). Madrid: WTO, 1997.

[20] Hemsley-Brown, J. V. \& Oplatka, I., "Universities in a competitive global marketplace: a systematic review of the literature on higher education marketing". International Journal of Public Sector Management, 19(4), 316-338, 2006.

[21] Formica, S., "European hospitality and tourism education: differences with the American model and future trends". International Journal of Hospitality Management, 15(4), 317-323, 1996.

[22] Mayburry, T. \& Swanger, N. A., "Identification of industry needs for baccalaureate hospitality graduates: a Delphi study". International CHRIE Conference-Refereed Track, Paper 4, $28-31$ July, San Juan - Puerto Rico, USA, 2010. Accessed 22 October, 2018. Retrieved from http://scholarworks.umass.edu/cgi/viewcontent.cgi?article=1281\&context=refereed.

[23] Brito, S.P., Notas sobre a evolução do viajar e a formação do Turismo. Lisboa: Medialivros, 2003.

[24] Cunha, L., Economia e Política do Turismo. Lisboa: Editorial Verbo, 2006.

[25] Salgado, M. \& Costa, C., "Ensino Superior na área do Turismo em Portugal". Revista Brasileira de Docência, Ensino e Pesquisa em Turismo, 1(2), 2-16, 2009.

[26] Eurico, S., "Ensino Superior em Turismo: satisfação e empregabilidade". Unpublished PhD Thesis. Faro: Universidade do Algarve, 2011.

[27] Schön, "Influencia de los factores del marketing de servicio en la elección de estudios superiores de turismo en instituciones públicas - los casos de España y Portugal" Unpublished PhD Thesis. Badajoz, Spain, 2016 
[28] Moreland, N., Entrepreneurship \& Higher Education: An Employability Perspective, Learning \& employability Series, ESECT, York, 2006.

[29] Wang, Y.-F.\& Tsai, C.-T., "Employability of Hospitality Graduates: Student and Industry Perspectives". Journal of Hospitality \& Tourism Education, 26, 125-135, 2014.

[30] Wakelin-Theron, "N. Employability development in Higher education institutions: a student perspective". African Journal of Hospitality, Tourism and Leisure, 3 (1), 1-16, 2014.

[31] Ladkin, A. \& Weber, K., "Tourism and hospitality academics: career profiles and strategies". Journal of Teaching in Travel and Tourism, 8 (4), 373-393, 2008.

[32] Nickson D., Human Resource Management for the hospitality and tourism industries, ButterworthHeinemann, 2007.

[33] Keep, E., and Mayhew, K., "The assessment: Knowledge skills, and competitiveness". Oxford Review of Economic Policy, 15 (1), 1-15, 1999.

[34] Hayes, D. K. \& Ninemeier, J. D., Human Resources Management in the Hospitality industry. Wiley, John Wiley \& Sons, Inc., Hoboken, New Jersey, 2009. Hemsley-Brown, J. V. \& Oplatka, I., "Universities in a competitive global marketplace: a systematic review of the literature on higher education marketing". International Journal of Public Sector Management, 19(4), 316-338, 2006.

[35] Chiavenato, I., Recursos Humanos. Grupo Editorial Elsevier, 2009 